\title{
Characterization of Trypanosoma rangeli Strains Isolated in Central and South America: an Overview
}

\author{
Edmundo C Grisard/ ${ }^{+}$, Mário Steindel, Alessandra A Guarneri, Iriane \\ Eger-Mangrich, David A Campbell*, Alvaro J Romanha**
}

\begin{abstract}
Departamento de Microbiologia e Parasitologia, Universidade Federal de Santa Catarina, 88040-900
Florianópolis, SC, Brasil *Department of Microbiology and Immunology, UCLA School of Medicine, Los Angeles, CA, 90095-1747, USA **Centro de Pesquisas René Rachou-Fiocruz, 30190-002 Belo Horizonte, MG, Brasil
\end{abstract}

Trypanosoma rangeli is a hemoflagelate parasite that infects domestic and sylvatic animals, as well as man, in Central and South America. T. rangeli has an overlapping distribution with T. cruzi, the etiological agent of Chagas disease, sharing several animal reservoirs and triatomine vectors. We have isolated T. rangeli strains in the State of Santa Catarina, in southern Brazil, which dramatically increased the distribution area of this parasite. This brief review summarizes several studies comparing $\mathrm{T}$. rangeli strains isolated in Santa Catarina with others isolated in Colombia, Honduras and Venezuela. The different methods used include indirect immunofluorescence and western blot assays, lectin agglutination, isoenzyme electrophoresis and random amplified polymorphic DNA analysis, triatomine susceptibility, in vitro cell infection assays, and mini-exon gene analysis.

Key words: Trypanosoma rangeli - antigens - carbohydrates - random amplified polymorphic DNA isoenzymes - mini-exon gene - triatomine susceptibility

Trypanosoma rangeli (Tejera, 1920) is a hemoflagellate parasite that infects humans as well as domestic and wild animals in Central and South America. This parasite has an overlapping distribution with $T$. cruzi, the causative agent of Chagas disease, allowing the occurrence of single and/or mixed infections in both vertebrate and invertebrate hosts in a same geographical region. Furthermore, both parasites share a large number of animal reservoirs and triatomine bug vectors. $T$. rangeli can be detected in more than twenty animal genera distributed in five different animal orders (D'Alessandro \& Saravia 1992).

More than 2,600 human cases of T. rangeli infection have been described, with the first Brazilian cases detected in 1996 in the Amazon region (D’Alessandro \& Saravia 1992, Coura et al. 1996).

Despite its non-pathogenic characteristics for vertebrate hosts, $T$. rangeli infection induces a humoral immune response resulting in high antibody

This work was supported by Universidade Federal de Santa Catarina, Fundação Oswaldo Cruz, CNPq and Capes (Brazilian Government Agencies), Brazil. Edmundo Grisard is a grantee of Capes-Bex 1973/97-05.

+Corresponding author. Fax: +55-48-3319258 E-mail: grisard@ccb.ufsc.br

Received 12 November 1998

Accepted 19 January 1999 levels. The cross-reactivity with $T$. cruzi in serological assays is due to the similarity of their surface antigens, and is a serious problem for the diagnosis of Chagas disease since false-positive results can be expected (D'Alessandro \& Saravia 1992).

The great pleomorphism presented by T. rangeli in the invertebrate host, turns difficult to distinguish $T$. rangeli from $T$. cruzi based only on morphology (Urdaneta-Morales \& Tejero 1992).

Detection of $T$. rangeli infection in the mammalian host is usually based on the same serological (indirect immunofluorescence and Elisa) and parasitological techniques (hemoculture and xenodiagnosis) used for Chagas disease, allowing the occurrence of false-positive results of human Chagas disease diagnosis.

Although T. rangeli can be distinguished from T. cruzi using several biological, immunological, biochemical and molecular methods, the characteristic biological behavior in the invertebrate host is the best tool for distinguishing between them. $T$. rangeli has the ability to invade and develop in the hemolymph and salivary glands of triatomine bugs, and the transmission occurs through the bite of an infected triatomine (Fig. 1).

The taxonomic position of $T$. rangeli has been the subject of controversy. Although $T$. rangeli is classified currently as a stercorarian trypanosome (Hoare 1972), i.e., transmitted through contaminated feces, several different studies did not achieve infection using parasites present in experimentally 


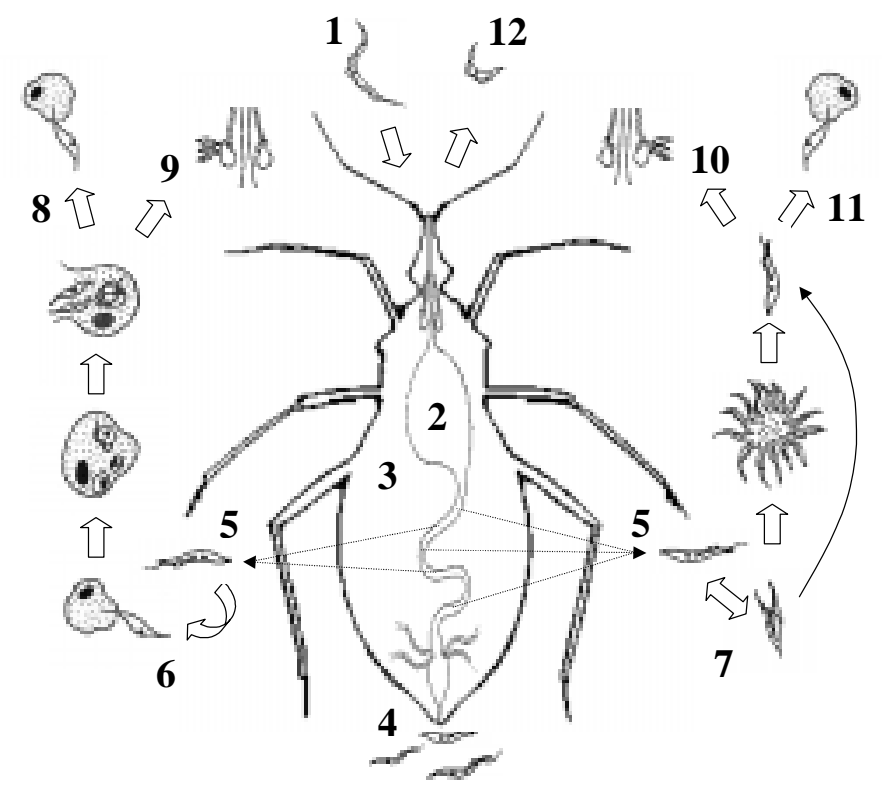

Fig. 1: schematic representation of Trypanosoma rangeli life cycle in the invertebrate host. (1) Infection of the triatomine is due to the ingestion of non-dividing blood trypomastigotes during probing. (2) After ingestion, the predominant forms in the midgut are epimastigotes and trypomastigotes. (3) Epimastigote forms escape the slender midgut and reach the hemocoel (5). Parasite forms can be usually detected in the feces (4). Once in the hemolymph, epimastigotes can invade and multiply within hemocytes (6) or divide as free parasites in the hemolymph (7). It is not clear if parasites derived from intra-hemocyte division are able to invade the salivary glands (8) or even re-invade hemocytes (9). Extracellular dividing parasites are able to directly invade and multiply within the salivary glands (10). It is also not clear if parasites derived from extracellular development can infect hemocytes (11). Metacyclic trypomastigotes (12) produced within the salivary glands are injected together with saliva during the feeding process (adapted with permission from D’Alessandro \& Saravia 1992).

or naturally-infected triatomine feces. Posterior transmission, however, can occur, but it is not the usual transmission mechanism of $T$. rangeli to the vertebrate host (D'Alessandro \& Saravia 1998).

Being within the Subgenus Herpetosoma, T. rangeli shares many characteristics of both Salivaria (transmitted through saliva) and Stercoraria, however it is clear that the principal mechanism of $T$. rangeli to the vertebrate host is by the bite of infected triatomines, mainly from the genus Rhodnius. T. rangeli produces pathogenic effects to the invertebrate hosts only, such as difficulty in the molt and retarded development of nymphs (D'Alessandro \& Saravia 1992, 1998).

Different methods have been used to characterize $T$. rangeli strains and to differentiate this parasite from T. cruzi. T. rangeli strains isolated in the State of Santa Catarina are genetically distinct from strains isolated from different geographical regions by kDNA analysis and DNA fingerprinting (Macedo et al. 1993, Vallejo et al. 1996). In both studies, $T$. cruzi strains formed a quite distinct group.

Recently, another group used the 18S rRNA as a genetic marker to build an evolutionary tree for human and primate trypanosomes and observed that the single $T$. rangeli strain isolated from a dog in Venezuela was grouped within the cruzi-clade, together with the bat trypanosomes T. marinkellei, T. dionisii, T. vespertilionis, that are not transmitted by triatomine bugs, and with $T$. cruzi that is transmitted through feces (Stevens et al. 1998).

While differences are observed among different strains and/or vectors, the life cycle of T. rangeli in the invertebrate hosts is well known (Fig. 1). However, the life cycle of this parasite in the vertebrate host(s) remains unclear due to conflicting observations (D'Alessandro 1976, Urdaneta-Morales \& Tejero 1985, Scorza et al. 1986, D'Alessandro \& Saravia 1998).

The finding of T. rangeli in Florianópolis, Santa Catarina, dramatically increased the reported distribution area of this parasite (Steindel et al. 1991). Thereafter, it was also found in other Brazilian states (Diotaiuti et al. 1992, Coura et al. 1996, Ramirez et al. 1998) (Fig. 2). Our aim has been to characterize the $T$. rangeli strains isolated in Santa Catarina, as well as to compare these strains with others isolated from different hosts, vectors and geographical regions. This brief review resumes the results of comparisons made with $T$. rangeli strains isolated from Santa Catarina, Colombia, Honduras and Venezuela using a variety of methods. 


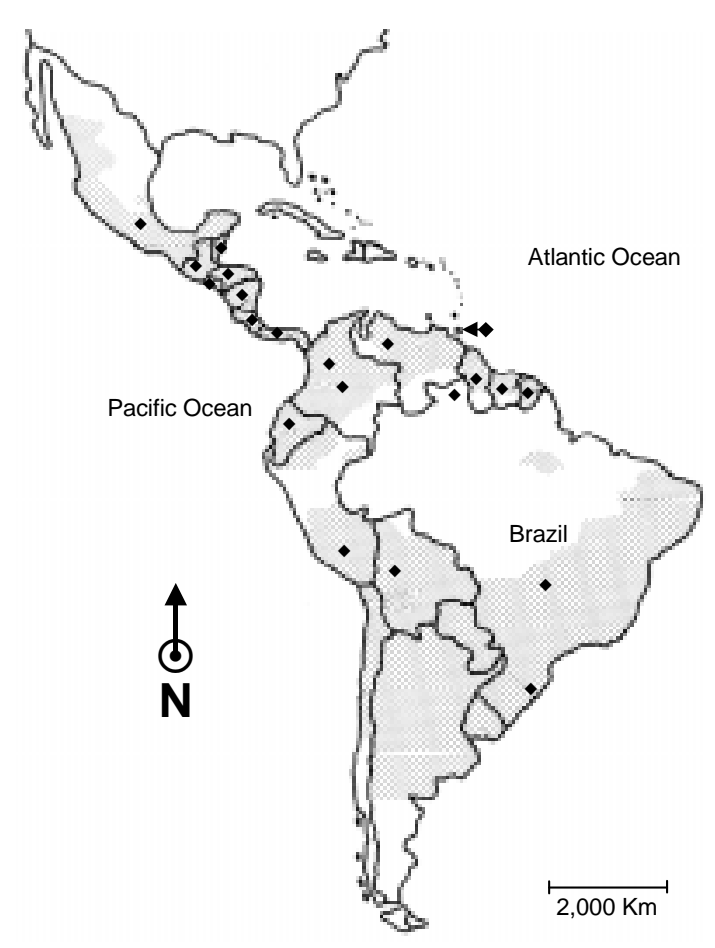

Fig. 2: map of Central and South America showing the overlapping distribution of human Chagas disease in 1992 (gray background) and the existing reports of Trypanosoma rangeli presence in humans, triatomines or wild animals $(\bullet)$ (adapted from WHO Technical report series \# 811 - Control of Chagas Disease).

\section{MATERIALS AND METHODS}

Parasites and strains - The parasites used in this work, as well as their geographic origins and original hosts, are presented in Table and Fig. 2.

Indirect immunofluorescence (IFA) and western blot assays - In order to differentiate $T$. rangeli from $T$. cruzi on the basis of their antigenic variability, these assays were performed with four antiT. cruzi (C27F, C44D3, CB2 and C2C3D3) and ten anti- $T$. rangeli $(1 \mathrm{~B} 3,2 \mathrm{C} 7, \mathrm{E} 9,5 \mathrm{~B} 8,5 \mathrm{H} 8,4 \mathrm{~B} 9$, 4A12, 4F4, 2B12 and 3A1) monoclonal antibodies (Mab) as described by Anthony et al. (1981).

Western blot assays were done using these same antibodies, following the method described in Towbin et al. (1979).

Lectin agglutination assays - This assay was used to compare the antigenic variability among $T$. rangeli strains isolated from different geographical regions. Lectin agglutination assays were performed with WGA lectin from Triticum vulgaris, known as T. cruzi agglutinant, and VVA lectin from Vicia villosa as described by Schottelius and Muller (1984).

Isoenzyme and random amplified polymorphic DNA analysis (RAPD) assays - Isoenzyme and RAPD profiles were carried out in order to compare the $T$. rangeli strains' phenotypic and genotypic characteristics, as well as to differentiate this parasite from T. cruzi (Steindel et al. 1994). Five different enzymes were analyzed: glucose phosphate isomerase (E.C. 5.3.1.9), alanine aminotransferase

TABLE

Parasites and strains used in this study, their geographic origins and hosts

\begin{tabular}{llclll}
\hline Parasite & Strain & Zymodeme & Origin & Host & Reference \\
\hline Trypanosoma rangeli & SC-58 & - & Brazil & Echimys dasytrhix & Steindel et al. 1991 \\
& SC-66 & - & Brazil & Echimys dasytrhix & Steindel et al. 1991 \\
& H -9 & - & Honduras & Human & Acosta et al. 1991 \\
& H - 14 & - & Honduras & Human & Acosta et al. 1991 \\
& H8GS & - & Honduras & Human & Acosta et al. 1991 \\
& Palma-2 & - & Venezuela & Rhodnius prolixus & Steindel et al. 1994 \\
& P-19 & - & Colombia & Rhodnius prolixus & Schottelius 1987 \\
& Choachi & - & Colombia & Rhodnius prolixus & Schottelius 1987 \\
& San Agustin & - & Colombia & Human & Tibayrenc et al. 1993 \\
& Macias & - & Venezuela & Human & Steindel et al. 1994 \\
& SC-3 & Z1 & Brazil & Panstrongylus megistus & Steindel et al. 1994 \\
& SC-51 & Z2 & Brazil & Panstrongylus megistus & Steindel et al. 1994 \\
& CL & ZB & Brazil & Triatoma infestans & Brener \& Chiari 1963 \\
& 254 & ZC & Brazil & Human & Carneiro et al. 1990 \\
\hline
\end{tabular}


(E.C. 2.6.1.2), malic enzyme (E.C. 1.1.1.40), phosphoglucomutase (E.C. 2.7.5.1) and aspartate aminotransferase (E.C. 2.6.1.1) as previously described (Carneiro et al. 1990). This method is able to make correlations between T. cruzi strains and the environment from which it was isolated, i.e., sylvatic, peri-domestic or domestic (Carneiro et al. 1990).

RAPD analysis was used to obtain an overview of the genomic variability among the $T$. rangeli strains. Six different oligonucleotides were used (Steindel et al. 1994), and the data obtained were analyzed by Dice similarity coefficient, the results of which were used in unweighted pair group method analysis (UPGMA) in order to produce phenetic trees that quantitate the genetic distance between these strains.

Triatomine susceptibility - We have studied the susceptibility of different triatomine species to $T$. rangeli SC-58, SC-61, Choachi and Macias strains. This study was carried out because correlations between parasites and local triatomine vectors have been shown for other triatomines species and $T$. rangeli strains (Grewal 1956, Tobie 1964, Cuba Cuba 1973). Adults and fifth instar nymphs of Rhodnius domesticus, $R$. prolixus. R. neglectus, and $R$. nasutus were fed with $T$. rangeli culture forms and the feces, the hemolymph, or saliva were screened by light microscopy for the presence of flagellates at different time points. These triatomines were maintained at $28 \pm 2^{\circ} \mathrm{C}$ and humidity $75 \pm 5 \%$.

Cell infection assays - Due to controversial observations about the $T$. rangeli life cycle within the vertebrate host, allied to the fact that this parasite is transmitted by triatomine bugs that are capillary feeders, we investigated the interaction in vitro of T. rangeli with different mammalian cell lines. T. rangeli $\mathrm{SC}-58, \mathrm{SC}-58$ clone $\mathrm{B} 1$ and Choachi strains were compared. Infection assays were performed with mouse peritoneal macrophages, VERO, L-929 and murine promonocyte (J774-G) cell lines. These assays were performed as described by Toma (1994).

Mini-exon gene comparison assays - T. rangeli San Agustin, Choachi, Palma-2, H8GS, Macias and SC-58 strains, as well as two clones of this strain (cl26 and cl32) where compared at the miniexon gene level. Four PCR oligonucleotides (TrINT-1, 2, 3 and 4) designed to anneal within the variable intergenic region of this tandemlyrepeated nuclear gene and to the $5 \mathrm{~S}$ rRNA gene, which is contained in the same repeats, were used (Grisard \& Romanha 1997).

To search for sequence polymorphisms within these amplified fragments, we used the low stringency single specific primer-PCR (LSSP-PCR) technique as described by Pena et al. (1993). Also, the mini-exon gene repeat of SC-58 (Santa Catarina) and H8GS (Honduras) strains were amplified by PCR performed with oligonucleotides ME-L and ME-R described by Murthy et al. (1992) using conditions described by Fernandes et al. (1997), then cloned and sequenced.

\section{RESULTS AND DISCUSSION}

Indirect immunofluorescence (IFA) and western blot assays - In IFA, all anti-T. cruzi Mabs tested did not react with any of the T. rangeli strains. All anti- $T$. rangeli Mabs reacted strongly with the central and northern South America T. rangeli strains; however, only four out of these ten anti-T. rangeli Mabs tested gave a weak reaction with $T$. rangeli strains isolated in Santa Catarina (Steindel 1993). These results clearly show that $T$. rangeli strains isolated in Santa Catarina have differences in their surface antigenic constitution when compared to other strains isolated from more northerly geographical regions.

Problematically, when we carried out western blot assays with $T$. rangeli SC-58 strain using one anti-T. rangeli $\mathrm{Mab}(2 \mathrm{C} 7)$ and one anti- $T$. cruzi $\mathrm{Mab}(\mathrm{C} 27 \mathrm{~F})$, the strain was only recognized by the C27F Mab (Steindel 1993). More studies must be performed to better understand the $T$. rangeli antigenic variation among strains isolated from different geographical regions, since $T$. rangeli and $T$. cruzi share $60 \%$ of their soluble antigenic coat (Afchain et al. 1979).

Lectin agglutination assays - Agglutination assays performed with WGA lectin from Triticum vulgaris were negative with the $T$. rangeli strains tested (SC-58 and H-14). Using very high concentrations $(>625 \mu \mathrm{g} / \mathrm{ml})$ of this lectin, some agglutination was observed. As expected, T. cruzi Y strain epimastigotes showed strong agglutination at lower concentrations of this lectin $(25 \mu \mathrm{g} / \mathrm{ml})$.

Using the VVA lectin from Vicia villosa, known to agglutinate other $T$. rangeli strains, we did not observe any agglutination with strains isolated in Santa Catarina (Steindel 1993). In agreement with the immunofluorescence assays, lectin agglutination differences also revealed a variation in antigenic constitution for Santa Catarina strains.

Isoenzyme and RAPD assays - Both techniques revealed that $T$. rangeli strain SC-58 was similar, but genetically distinct from those isolated from the other geographical regions (H-9, H-14, Choachi, P19, San Agustin, Macias, Palma-2), and quite different from T. cruzi strains (Steindel et al. 1994).

The isoenzyme profiles obtained with the five enzymes revealed that $T$. rangeli strains isolated in Santa Catarina shared the migration pattern of the other $T$. rangeli strains only for the malic enzyme, and was quite distinct for the others. T. cruzi strain 
(SC-66) and standard zymodemes (Z1, Z2, ZB and $\mathrm{ZC})$ patterns were quite distinct from those obtained for $T$. rangeli strains.

At the DNA level, the RAPD profiles obtained with six different PCR oligonucleotides revealed a polymorphic pattern among these strains. After data analysis through unweighted pair grouped method analysis - UPGMA (Sneath \& Sokal 1962), two different groups were formed according to the Dice similarity coefficient (Dice 1945): one with T. rangeli strains isolated in central and northern areas of South America (Choachi, Macias, San Agustin, H8GS, H9, H14, P19, Palma-2), and another formed by $T$. rangeli strains isolated in Santa Catarina (SC-58 and SC-61).

In conclusion, the isoenzyme analysis is capable of differentiating $T$. rangeli from $T$. cruzi. RAPD profiles analysis is also able to differentiate these parasites, providing sufficient data to make phylogenetic inferences.

Triatomine susceptibility - A high correlation between the strain and the local vector was observed as described in the literature (Cuba Cuba et al. 1972, D'Alessandro 1972, Rosa et al. 1995). The SC-58 strain isolated in Santa Catarina was at least ten times more infective for the presumptive local vector $R$. domesticus than for $R$. prolixus. Strains isolated from Central America were less infective for $R$. domesticus than for $R$. prolixus (Steindel \& Guarneri 1996).

Because $R$. domesticus is the only triatomine species of this genus that can be found in Florianópolis, we hypothesize that it is the natural vector for T. rangeli in this area. Another occuring species, such as Panstrongylus megistus, do not allow $T$. rangeli to escape the gut and develop in the hemolymph and within the salivary glands. Natural mixed infections with $T$. rangeli and $T$. cruzi were only detected in feces of $P$. megistus bugs at the same locality, however, we have never observed natural $T$. rangeli infection in $R$. domesticus bugs in Florianópolis (Steindel et al. 1994).

Experimental infection of $R$. neglectus, $R$. prolixus and $R$. nasutus with $T$. rangeli SC-58, SC61, Choachi and Macias strains revealed that their infection rate and ability to transmit $T$. rangeli isolated from Santa Catarina were significantly lower when compared with Choachi and Macias strains (Rosa et al. 1995). This geographical correlation between vectors and strains are in agreement with the results obtained by RAPD profile analysis, confirming the genetic variability between these parasite populations. In addition, the pathogenic effect of $T$. rangeli infection for triatomines described in the literature (Tobie 1964, Cuba Cuba et al. 1972, D'Alessandro 1972), i.e. retarded development and difficulty in blood feeding and molting, were found for $R$. domesticus infected with SC-58 strain (Guarneri et al. 1997).

Cell infection assays - We have studied the interaction of $T$. rangeli with mouse peritoneal macrophages. After $24 \mathrm{hr}$ we observed less than $10 \%$ of the cells containing the characteristic, but nondividing, "amastigote-like" form. After $48 \mathrm{hr}$ of interaction, these parasite forms completely disappear and no free swimming parasites were seen (Eger et al. 1996).

Results obtained with the other cell lines tested showed the same intracellular non-dividing forms (Eger et al. 1997). These cell lines sustained the infection for longer periods than those observed for mouse peritoneal macrophages, but they could not sustain the infection for more than five days under our experimental conditions. Using a histiocytic cell line (U937) and a different $T$. rangeli strain proven to be not contaminated with $T$. cruzi, Osorio et al. (1995) observed intracellular dividing amastigotes which were able to infect $R$. prolixus per os.

Because triatomines are capillary feeders, $T$. rangeli is transmitted through direct inoculation together with saliva into vertebrate host bloodstream during the feeding process. Some of the tested cell lines are the first non-specific immune defense barrier on the vertebrate organism, thus it seems that $T$. rangeli infectivity and development within these cells, at least in vitro, seems to be a strain-dependent phenomen. Different cell lines as well as in vivo studies are being pursued in the mouse model to better adress this question.

Mini-exon gene assays - Although the TrINT oligonucleotides can specifically detect $T$. rangeli DNA in feces of experimentally infected triatomines, their capacity of detection decreases in the presence of excess of host DNA (Grisard et al. 1997).

In LSSP-PCR assays, highly conserved patterns among strains isolated in central and northern areas of South America were observed by gel electrophoresis. This assay also revealed the existence of sequence polymorphism at the mini-exon gene level between these $T$. rangeli strains and SC-58 strain, as well as in the two clones of this strain obtained by limitant dilution.

Comparative analysis of the sequences obtained for SC-58 (GenBank acession \# AF083350) and H8GS (GenBank acession \# AF083351) mini-exon gene with other $T$. rangeli and $T$. cruzi sequences in the GenBank revealed a conservation within the exon, the intron, and the 5S rRNA portions of the repeat. In contrast, homologous recombination and microsatellite variability occur in the non-transcribed regions (EC Grisard et al., in press).

As observed for T. cruzi, different degrees of polymorphism among $T$. rangeli strains isolated 
from different geographical regions, hosts and vectors were detected using different methods. Despite these differences, all $T$. rangeli strains used in this study maintained their capacity to invade and multiply in hemolymph and salivary glands of the triatomine bugs. Attempts to infect mice with $T$. rangeli strains isolated in Santa Catarina with parasite forms derived from experimentally infected triatomine feces was never achieved.

Modern biochemical, immunological and molecular methods have been used for trypanosomatid characterization and taxonomy. Results derived from these analyses must always be compared with biological features. The number of strains analyzed, their biological behavior in both invertebrate and vertebrate hosts, their geographical origin, the isolation and methods of maintenance and known polymorphisms observed among different strains can interfere in these analysis.

Our biological, immunological and molecular studies have shown that $T$. rangeli strains isolated from Santa Catarina, in the south of Brazil, are genetically variant from those isolated from central and northern South America. In all assays, $T$. cruzi strains used as controls formed distinct groups.

We believe that future taxonomic or phylogenetic data obtained from these well-characterized strains will be a powerful tool to better understand the epidemiology of T. rangeli in Central and South America, as well as the evolutionary pathways of this trypanosome. Furthermore, these studies warn that the presence of $T$. rangeli can be expected in the same distribution area as T. cruzi, which constitutes a complication for the Chagas disease diagnosis and epidemiology.

\section{ACKNOWLEDGMENTS}

To Dr Michel Dollet and Dr Nancy R Sturm for comments and suggestions on this manuscript. To Dr Antonio D'Alessandro for helpful comments on the Trypanosoma rangeli life cycle and epidemiology. To Dr Maria Sonia Martins who kindly donated the monoclonal antibodies used in this study and to Gusti Zeiner for help on the drawings.

\section{REFERENCES}

Acosta L, Romanha AJ, Cosenza K, Krettli AU 1991. Trypanosomatid isolates from Honduras: Differentiation between Trypanosoma cruzi and Trypanosoma rangeli. Am J Trop Med Hyg 44: 676-683.

Afchain D, LeRay D, Fruit J, Capron A 1979. Antigenic make-up of Trypanosoma cruzi culture forms: Identification of a specific component. J Parasitol 65: 507-514.

Anthony RL, Cody T, Constatine NT 1981. Antigenic differentiation of Trypanosoma cruzi and Trypanosoma rangeli by means of monoclonal-hybridoma antibodies. Am J Trop Med Hyg 30: 1192-1197.

Brener Z, Chiari E 1963. Variações morfológicas observadas em diferentes amostras de Trypanosoma cruzi. Rev Inst Med Trop São Paulo 5: 220-224.

Carneiro M, Chiari E, Gonçalves AM, Silva Pereira AA, Morel CM, Romanha AJ 1990. Changes in the isoenzyme and kinetoplast DNA patterns of Trypanosoma cruzi strains induced by maintenance in mice. Acta Trop 47: 35-45.

Coura JR, Fernandes O, Arboleda M, Barret TV, Carrara N, Degrave W, Campbell DA 1996. Human infection by Trypanosoma rangeli in the Brazilian Amazon. Trans R Soc Trop Med Hyg 90: 278-279.

Cuba Cuba, CA 1973. Evolução de uma Cepa Peruana de Trypanosoma rangeli em Rhodnius ecuadoriensis e Panstrongylus herreri, MSc, Thesis, Universidade Federal de Minas Gerais, Belo Horizonte, MG.

Cuba Cuba C, Morales N, Fernández E, Fernández W 1972. Hallazgo de Rhodnius equatoriensis Lent \& León, 1958 infectado naturalmente por trypanosomas semejantes a Trypanosoma rangeli Tejera, 1920 en caserios del districto de Cascas, Contumazá, Depto. de Cajamarca, Peru. Rev Inst Med Trop São Paulo 14: 191-202.

D'Alessandro A 1972. New exprimental vectors of Colombian Trypanosoma rangeli. J Med Entomol 9: 187-195.

D'Alessandro A 1976. Biology of Trypanosoma (Herpetosoma) rangeli Tejera, 1920, p. 187-195. In Biology of Kinetoplastida, Vol. 1, Academic Press, London.

D’Alessandro A, Saravia NG 1992. Trypanosoma rangeli, p. 1-54. In Parasitic Protozoa, 2nd ed., Vol. 2, Academic Press, San Diego.

D'Alessandro A, Saravia NG 1998. Trypanosoma rangeli. In Hanbook of Protozoal Infection, in press.

Dice LR 1945. Measures of the amount of ecological associations between species. Ecology 26: 297-302.

Diotaiuti L, Silveira AC, Elias M, Steindel M 1992. The possibility of occurrence of Trypanosoma rangeli in the State of Tocantins, Brazil. Mem Inst Oswaldo Cruz 87: 451.

Eger I, Grisard EC, Steindel M 1996. In vitro interaction of Trypanosoma rangeli with macrophages and Vero cells. Mem Inst Oswaldo Cruz 91 Suppl.: 104.

Eger I, Grisard EC, Steindel M 1997. Absence of in vitro multiplication of Trypanosoma rangeli within a murine promonocyte cell line. Mem Inst Oswaldo Cruz 92 Suppl: 105.

Fernandes O, Teixeira, MMG, Sturm NR, Sousa MA, Camargo EP, Degrave W, Campbell DA 1997. Miniexon gene sequences define six groups within the Genus Crithidia. J Euk Microbiol 44: 535-539.

Grewal MS 1956. Trypanosoma rangeli Tejera, 1920 in its vertebrate and invertebrate hosts. Trans $R$ Soc Trop Med Hyg 50: 301-302.

Grisard EC, Campbell DA, Romanha AJ 1998. Characterization of Trypanosoma rangeli strains isolated in Central and South America. Parasitology in press.

Grisard EC, Machado EMM, Alvarenga NJ, Romanha AJ 1997. Easy detection of Trypanosoma rangeli and Trypanosoma cruzi DNA in experimentally infected triatomines by polymerase chain reaction, p. 231, XI Congresso Soc Bras Parasitologia, Sal- 
vador, BA, Brasil.

Grisard EC, Romanha AJ 1997. Mini-exon gene variability among Trypanosoma rangeli strains isolated from different geographic regions detected by low stringency single specific primer-PCR (LSSP-PCR). Mem Inst Oswaldo Cruz 92 Suppl.: 189.

Guarneri AA, Carvalho Pinto CJ, Steindel M 1997. Comparison of the evolutive cycle of Rhodnius domesticus (Hemiptera: Reduviidae) infected and non-infected with Trypanosoma rangeli. Mem Inst Oswaldo Cruz 92 Suppl.: 287.

Hoare C 1972. The Trypanosomes of Mammals: A Zoological Monograph, p. 288-314, Blackwell Scientific Publications, Oxford, UK.

Macedo AM, Vallejo GA, Chiari E, Pena SDJ 1993. DNA fingerprinting reveals relationships between strains of Trypanosoma rangeli and Trypanosoma cruzi, p. 321-329. In DNA Fingerprinting: State of the Science, Birkhäuser Verlag, Basel, Switzerland.

Murthy VK, Dibbern FM, Campbell DA 1992. PCR amplification of mini-exon gene differentiates Trypanosoma cruzi from Trypanosoma rangeli. Mol Cell Probes 6: 237-243.

Osorio Y, Travi BL, Palma GI, Saravia NG 1995. Infectivity of Trypanosoma rangeli in a promonocytic mammalian cell line. J Parasitol 81: 687-693.

Pena SDJ, Barreto G, Vago AR, Marco LD, Reinach FC, Dias Neto E, Simpson AJG 1993. Sequencespecific "gene-signatures" can be obtained by PCR with single specific primers at low stringency. Proc Nat Acad Sci USA 91: 1946-1949.

Rosa G, Oliveira MA, Grisard EC, Steindel M 1995. Susceptibility of triatomines from the genus Rhodnius to a different strains of Trypanosoma rangeli. Mem Inst Oswaldo Cruz 90 Suppl.: 229.

Ramirez LE, Machado MI, Maywald PG, Matos A, Chiari E, Silva EL 1998. Primeira evidência de Trypanosoma rangeli no sudeste do Brasil, região endêmica para a doença de Chagas. Rev Soc Bras Med Trop 31: 99-102.

Scorza C, Urdaneta-Morales S, Tejero F 1986. Trypanosoma (Herpetosoma) rangeli Tejera, 1920: preliminary report on histopathology in experimentally infected mice. Rev Inst Med Trop São Paulo 28: 371-378.

Schottelius J 1987. Neuraminidase fluorescent test for differentiation of Trypanosoma cruzi and Trypanosoma rangeli. Trop Med Parasitol 38: 323-327.

Schottelius J, Muller V 1984. Interspecific differentiation of Trypanosoma cruzi, Trypanosoma conorhini and Trypanosoma rangeli by lectins in combination with complement lysis. Acta Trop 41: 29-38.

Sneath PHA, Sokal RR 1962. Numeric taxonomy. $\mathrm{Na}$ ture 193: 853-860.

Steindel M 1993. Caracterização de Cepas de Trypano- soma rangeli e Trypanosoma cruzi Isoladas de Reservatórios e Vetores Silvestres em Santa Catarina, PhD Thesis, Universidade Federal de Minas Gerais, Belo Horizonte, 165 pp.

Steindel M, Guarneri AA 1996. Interaction of trypanosomes with different triatomine species. Mem Inst Oswaldo Cruz 91 Suppl.: 32-33.

Steindel M, Carvalho Pinto CJ, Toma HK, Mangia RHR, Ribeiro-Rodrigues R, Romanha AJ 1991. Trypanosoma rangeli Tejera, 1920 isolated from a sylvatic rodent (Echimys dasythrix) in Santa Catarina State: First report of this trypanosome in southern Brazil. Mem Inst Oswaldo Cruz 86: 73-79.

Steindel M, Dias Neto E, Ribeiro-Rodrigues R, Carvalho Pinto CJ, Grisard EC, Menezes CLP, Murta SMF, Simpson AJG, Romanha AJ 1994. Randomly amplified polymorphic DNA (RAPD) and isoenzyme analysis of Trypanosoma rangeli strains. J Euk Microbil 41: 261-267.

Stevens J, Noyes H, Gibson W 1998. The evolution of trypanosomes infecting humans and primates. Mem Inst Oswaldo Cruz 93: 669-676.

Tibayrenc M, Neubauer K, Barnabe C, Guerrini F, Skarecky D, Ayala FJ 1993. Genetic characterization of six parasitic protozoa: parity between randomprimer DNA typing and multilocus enzyme electrophoresis. Proc Nat Acad Sci USA 90: 1335-1339.

Tobie EJ 1964. Increased infectivity of a cyclically maintained strain of Trypanosoma rangeli to Rhodnius prolixus and mode of transmission by invertebrate host. J Parasitol 50: 593-598.

Toma HK 1994. Interação in vitro de Cepas de Trypanosoma cruzi de Parasitemia Alta e Subpatente in vivo com Diferentes Linhagens Celulares, Msc Thesis, Universidade Federal de Minas Gerais, Belo Horizonte, 75 pp.

Towbin H, Staehlin T, Gordon J 1979. Electrophoretic transfer of protein from polyacrylamide gels to nitrocellulose sheets: procedure and some aplications. Proc Natl Acad Sci USA 76: 4350.

Urdaneta-Morales S, Tejero F 1985. Trypanosoma (Herpetosoma) rangeli Tejera, 1920: Mouse model for high, sustained parasitemia. J Parasitol 71: 409.

Urdaneta-Morales S, Tejero F 1992. Trypanosoma rangeli (Tejera, 1920): observations upon pleomorphism. Mem Inst Oswaldo Cruz 87: 511-516.

Vallejo GA, Guhl F, Chiari E, Pena SDJ, Macedo AM 1996. Detection of Trypanosoma cruzi and Trypanosoma rangeli in vector and mammalian hosts by polymerase chain reaction amplification of kinetoplast minicircle DNA. Mem Inst Oswaldo Cruz 91 Suppl.: 296.

WHO-World Health Organization 1991. Control of Chagas disease, WHO Technical report series 811, Geneva, 95 pp. 
210 Characterization of T. rangeliStrains - Edmundo C Grisard et al. 